\title{
Cytotoxic Effects of Alchemilla mollis (Buser) Rothm. Extracts on MCF 7 Cell Line ${ }^{\dagger}$
}

\author{
Selen İlgün 1, Gökçe Şeker Karatoprak ${ }^{2, *}$ and Müberra Koşar ${ }^{3}$ \\ 1 Faculty of Pharmacy, Department of Pharmaceutical Botany, Erciyes University, Kayseri 38039, Turkey; \\ erturkselen@g-mail.com \\ 2 Faculty of Pharmacy, Department of Pharmacognosy, Erciyes University, Kayseri 38039, Turkey \\ 3 Faculty of Pharmacy, Department of Pharmacognosy, Eastern Mediterranean University, Gazimağusa, \\ North Cyprus via Mersin 10, Turkey; muberrakosar@gmail.com \\ * Correspondence: gskaratoprak@gmail.com; Tel.: +09-0505-488-94-06 \\ + Presented at the 2nd International Conference on Natural Products for Cancer Prevention and Therapy, \\ Kayseri, Turkey, 8-11 November 2017.
}

Published: 14 November 2017

\begin{abstract}
Alchemilla is a genus of herbaceous perennial plants in the Rosaceae, with the common name Lady's Mantle. Aerial part of the plant which is used medicinally, traditionally used for skin irritations, wounds, female conditions such as menorrhagia, menopause and painful periods. Alchemilla mollis (Buser) Rothm. which grown in Black Sea Region of Turkey were investigated for its cytotoxic activities on MCF 7 cell line with SRB method A. mollis herb material was extracted with, methanol using a Soxhlet apparatus for $8 \mathrm{~h}$. and separately A. mollis herb material was extracted with water using reflux for $3 \mathrm{~h}$. Deodorized water extract of $A$. mollis was prepared using Clevenger apparatus. Results clearly demonstrated that the water extract of $A$. mollis has the highest cytotoxic effect among the other extracts. Water extract was significantly cytotoxic between the $62.5-$ $1000 \mu \mathrm{g} / \mathrm{mL}$ concentrations $(p<0.05)$. The IC 50 value of the water, deodorized water and methanol extracts are $59.34 \pm 3.41 \mu \mathrm{g} / \mathrm{mL}, 87.37 \pm 25.15 \mu \mathrm{g} / \mathrm{mL}, 68.18 \pm 6.12 \mu \mathrm{g} / \mathrm{mL}$, respectively. The cytotoxic activity on MCF7 cell line of the A. mollis was first studied by us and the results are promising. Further studies are needed to confirm in vivo anti-tumorgenicity and subsequent chemical characterization of the active molecule(s).
\end{abstract}

Keywords: Alchemilla mollis; cytotoxity; MCF 7

(C) 2017 by the authors. Licensee MDPI, Basel, Switzerland. This article is an open access article distributed under the terms and conditions of the Creative Commons Attribution (CC BY) license (http://creativecommons.org/licenses/by/4.0/). 